\title{
Profitability Analysis of Selected Farms in the Batinah Region of Oman
}

\author{
Fahad A. Al Said ${ }^{1}$, Slim Zekri ${ }^{2 *}$ and Iqrar A. Khan ${ }^{1}$ \\ ${ }^{1}$ Department of Crop Sciences / 2 Department of Agricultural Economics \\ and Rural Studies, College of Agricultural and Marine Sciences, \\ Sultan Qaboos University, P.O. Box 34, Al-khod 123, \\ Muscat, Sultanate of Oman \\ تحليل ربحي لمزارع مختارة في منطقة الباطنة، بسلطنة عمان

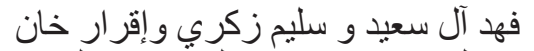

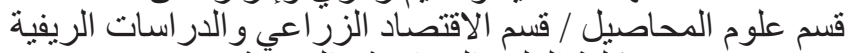

$$
\begin{aligned}
& \text { كلية العلوم الزر اعية والبحية الزئية }
\end{aligned}
$$

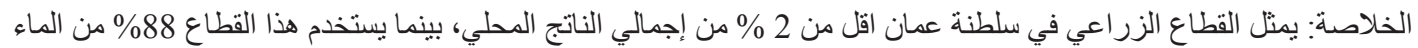

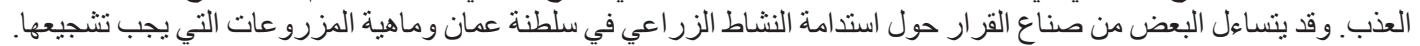

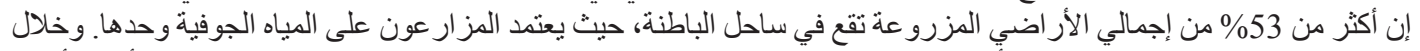

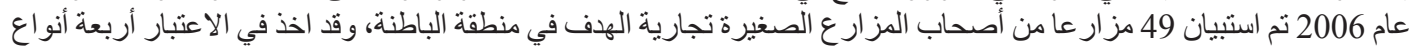

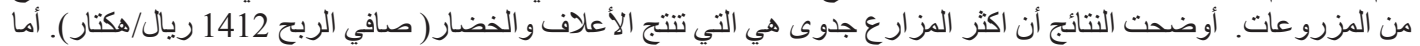

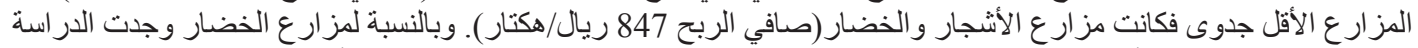

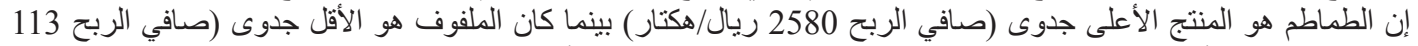

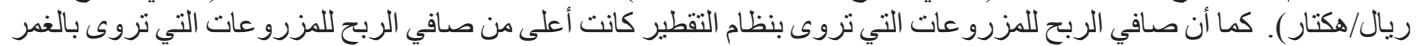

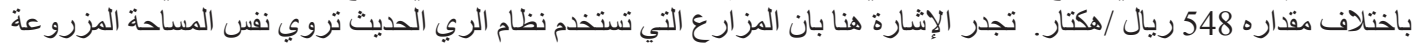

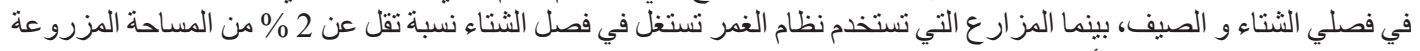

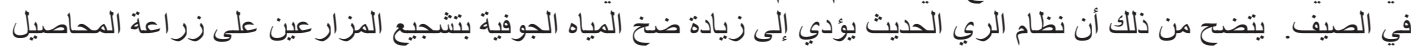

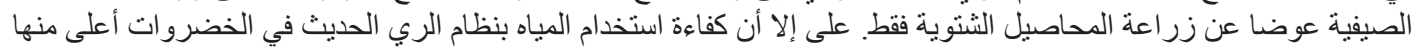

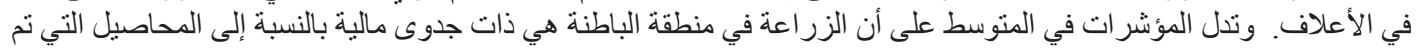

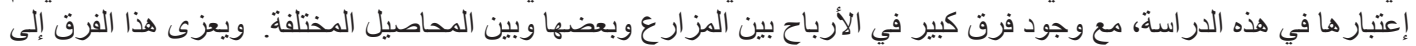

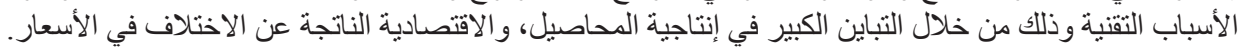

ABSTRACT: The agricultural sector of Oman represents less than $2 \%$ of the total GDP and uses $88 \%$ of the fresh water. Several decision makers are questioning whether the agricultural activity in the Sultanate of Oman can be sustained and if so what type of crops should be encouraged. More than 53\% of the agricultural cropped area is situated in the Batinah coastal area where farming is exclusively based on groundwater pumping. A sample of 49 market-oriented farms from the Batinah region was surveyed during 2006. Four types of farms were considered. Results showed that the most profitable farms are mixing fodder crops and vegetables with a net margin of 1,412 RO/ha/year. The less profitable farms are based on tree crops and vegetables with a net margin of $847 \mathrm{RO} /$ ha/year. For vegetables the most profitable crop is tomato with an average net margin of 2,580 RO/ha/year with a standard deviation of 2,043 RO/ha/year and the least profitable crop is cabbage with $113 \mathrm{RO} /$ ha/ year with a standard deviation of $182 \mathrm{RO} / \mathrm{ha} /$ year. The net margin of crops grown under drip irrigation is higher than that for crops under furrow irrigation, with a difference of $548 \mathrm{RO} / \mathrm{ha} /$ year. Farms equipped with such modern irrigation systems tend to irrigate almost the same area in winter as in summer, while farms under furrow irrigation crop less than one percent of their cropped area during summer compared to winter. Consequently and contrary to expectations, modern irrigation systems tend to increase, rather than reduce, groundwater pumping given the financial incentives for farmers to grow summer vegetables instead of only winter vegetables. Even so, the net water use efficiency is greater for vegetable production under drip irrigation 
than it is for fodder production. The figures show that, on average, farming in the Batinah is financially profitable for the types of farm considered in this study. However, profitability varies widely between different farms and crops. The reasons for these differences are technical, as observed in the big differences in yield among crops, and economic because the prices received by farmers differ significantly.

Keywords: Vegetables, Oman, salinity, irrigation, fodder crops, yields, profitability.

\section{Introduction}

The climatic and ecological diversity in Oman offers an opportunity to grow high-value, off-season vegetable crops, which have a ready market in the region as well as in distant markets. Off-season vegetable cultivation is feasible because of the mild winter climate. Exports of agricultural products reached $12.5 \%$ of Oman's non-oil exports in 2005 (Ministry of National Economy, 2007) and over 160,000 Omanis are fully or partially employed in the agricultural and fisheries sectors (Ministry of Agriculture and Fisheries, 2006). Despite these achievements the agricultural sector's performance remains unsatisfactory. In this article we consider improving the efficiency of water use and shifting to high-value vegetable crops in order to improve the productivity of the agricultural sector.

More than $53 \%$ of the cropped area in Oman is situated in the Batinah region and is totally dependent on groundwater (Ministry of Agriculture and Fisheries, 2006). Excessive water mining has caused seawater intrusion into the aquifer, leading to salinity problems in many locations. The soil salinity in the Batinah region ranges between $2 \mathrm{dS} / \mathrm{m}$ to $20 \mathrm{dS} / \mathrm{m}$; salinity is one of the most serious constraints in crop production.

Worldwide, over two billion people suffer from deficiencies of micronutrients in their diets (Gardner and Halweil, 2000). Such malnutrition prevents much of the world's population from reaching their full mental, physical and financial potential. It also contributes to higher rates of deaths caused by heart disease, stroke and cancer (Khaw et al., 2001). This situation can, in part, be remedied by increasing the supply and consumption of vegetables. It is important that the quantity and quality of vegetables used are of the highest possible standard. The diet in Oman is dominated by rice and is thus potentially deficient in Vitamin A; this suggests that greater research and extension efforts need to be applied to vegetable production and supply (Dellapenna, 2001).

Previous research in this field includes analysis of the demand for, and marketing of, vegetables in Oman
(Omezzine et al., 1998); studies on some aspects of salinity and fertilization of potatoes and tomatoes (Rehmatullah, 1996; Satti et al., 1995). However, studies that consider the profitability of both crops and farming systems are missing. The present paper attempts an assessment of the profitability of farms specializing in vegetable production and compares the results to profitability figures for other forms of agriculture in the same region of Oman. The paper also analyzes the impact of the adoption of modern irrigation systems and farmers' awareness of the problem of groundwater salinization. It provides a baseline for future analysis of the profitability of the farming sector. The paper concludes with a discussion on the possible implications for vegetable growers of a new policy on the production of fodder crops.

\section{Methodology}

Gross margins and net margins are used as indicators to estimate crop and farm profitability. Calculations are based on observations of farmers' inputs and production of outputs.

The gross margin $(\mathrm{GM})$ is defined as follows:

$$
\mathrm{GM}_{\mathrm{i}}=\text { Yield }_{\mathrm{i}} * \text { Price }_{\mathrm{i}}-\text { Variable costs }_{\mathrm{i}}
$$

where, yield $_{\mathrm{i}}=$ output in $\mathrm{kg} / \mathrm{ha}$ for crop $i$; price $_{\mathrm{i}}=$ price of output $i$ in Omani RO $/ \mathrm{kg}$; variable costs $=$ cost of seeds, fertilizers, agrichemicals, occasional labor and transport to market for crop $i$ in Omani RO/ha.

The weighted average gross margin per crop and group of farms is defined as follows:

$$
\mathrm{WGM}_{\text {ig }}=\sum \sum \mathrm{A}_{\mathrm{ifg}} * \mathrm{GM}_{\mathrm{ifg}} / \sum \mathrm{A}_{\mathrm{ifg}}
$$

where, $\mathrm{A}_{\mathrm{if}}=$ area of crop $i$ at farm $f$ in Group g; $\mathrm{GM}_{\mathrm{if}}=$ gross margin of crop $i$ at $\operatorname{farm} f$ in Group $g$.

The net margin (NM) at farm level is the return to land, capital and management and is defined as follows:

$$
\mathrm{NM}_{\mathrm{f}}=\underset{\text { energy }_{\text {if }}-\text { pest }_{\mathrm{f}}-\text { DCMIS }_{\mathrm{f}}}{\mathrm{WGM}_{\mathrm{f}}}
$$


Table 1. Survey sample and farm characteristics.

Group

\begin{tabular}{lccccc} 
& \multirow{2}{*}{ All farms } & 1 & 2 & 3 & 4 \\
\cline { 3 - 6 } & & Vegetables & $\begin{array}{c}\text { Tree Crops and } \\
\text { Vegetables }\end{array}$ & $\begin{array}{c}\text { Fodder and } \\
\text { Vegetables }\end{array}$ & Mixed \\
\hline Number & 49 & 23 & 17 & 5 & 4 \\
Total Area (ha) & 394 & 262 & 91 & 18.1 & 19 \\
Cropped Area (ha) & 289 & 207 & 54 & 14 & 14 \\
Cropped Area (\%) & 73 & 79 & 59 & 76 & 73 \\
Average Farm Size (ha) & 8.03 & 11.39 & 5.37 & 3.62 & 4.82 \\
Average Cropped Area (ha) & 5.90 & 9.00 & 3.18 & 2.76 & 3.49 \\
Area Occupied by Vegetables (\%) & 68 & 100 & 46 & 21 & 43 \\
Area Occupied by Trees (\%) & 25 & 0 & 54 & 0 & 23 \\
Area Occupied by Fodder (\%) & 7 & 0 & 0 & 79 & 33 \\
\hline
\end{tabular}

where, energy $\operatorname{cost}_{\mathrm{f}}=$ the cost of electricity or fuel used for pumping groundwater at farm $f$; DCMIS $_{\mathrm{f}}$ $=$ depreciation cost of the modern irrigation system at $\operatorname{farm} f$.

The net margin should not be interpreted as a net return because the cost of management, cost of capital and the opportunity cost of land are not accounted for.

\section{Data Collection}

A survey was run in the Batinah area of farms of over two hectares in size to determine crop mix, crop yields, and input use. More than 150 farms were visited but only 54 farmers were willing and able to answer the detailed questionnaire about input use and output. The total number of farms larger than two hectares in the Batinah region is 8,587 (MAF, 2006). The final number of farms retained for statistical analysis was 49 only, due to incoherent data in five surveys, which were removed from the sample. The sample thus represents only $0.6 \%$ of total farms larger than two hectares. This is due to the fact that most farmers do not keep any records related to input use and output marketing. Although the sample is statistically not representative the paper gives an overview of farming profitability in the Batinah region and focuses on farms with available information.

The farms were divided into four different groups according to the major types of crops grown. These groups are defined as follows:
- Group 1: Farms growing vegetables only.

- Group 2: Farms growing mainly perennial crops (e.g, dates, mangoes, citrus fruit), with some vegetables.

- Group 3: Farms growing mainly fodder crops, with some vegetables.

- Group 4: Mixed farms growing vegetables, fodder crops and perennials (dates, etc.).

Table 1 shows some characteristics of the surveyed farms. The average farm size is eight hectares. On average the cropped area represents only $73 \%$ of the total area with farmers in Group 1 cropping $79 \%$ of the total area and farmers in Group 2 cropping only $59 \%$ of the area. Seventy five percent of the farms are individually owned, with $25 \%$ of the farms owned by two or three siblings. Farming is the sole source of income for $37 \%$ of the farmers interviewed. The remaining farmers are either retired from previous occupations $(15 \%)$ or are part-time farmers with their main activity in the Government or private sector $(48 \%)$. Despite the small size of the farms, $60 \%$ of them employ permanent laborers and $40 \%$ of the farms use occasional labor. On average a permanent employee is paid $60 \mathrm{RO} /$ month plus food, housing, health insurance and travel costs. For the occasional labor, employees are paid $4 \mathrm{RO} /$ day in most cases.

\section{Results}

The results are presented on a crop-by-crop basis for each of the four groups of farms. Subsequently, group performances are compared. 


\section{Group 1: Farms growing only vegetables}

The average number of crops grown per farm in this group is six. The relatively large number of crops grown with respect to the small area denotes the absence of specialization despite the fact that farms are market oriented. The most important crops in terms of area are watermelon and melon with $31 \%$ and $27 \%$ of the cropped area respectively, followed by tomato (25\%) and cabbage ( $8 \%)$.

Comparing all crops, the highest average yield is observed in potato with $48 \mathrm{t} /$ ha (Table 2). Melon and watermelon registered average yields of 14 and 16 $\mathrm{t} /$ ha, respectively. Yields for cabbage and tomato were 4 and 38 t/ha, respectively. Yield differences among farms are very high, as is shown by the calculated standard deviations. Thus, for example, for melon and water melon the standard deviations were $7 \mathrm{t} / \mathrm{ha}$ for both crops and for tomato $26 \mathrm{t} / \mathrm{ha}$. These high standard deviations indicate that there are large possibilities for yield improvements in the Batinah region by the appropriate planning of extension programs for vegetable growers, focusing on the best management practices. The available data could serve as a basis for the selection of the best farmers for collection of further details on best management practices.
On average the variable costs for this type of farm are 1,662 $\mathrm{RO} /$ ha, with the highest cost observed for potato at 3,955 $\mathrm{RO} / \mathrm{ha}$. The last figure might explain why only one single farmer produced potatoes. In terms of profitability, the highest gross margin (GM) is obtained for tomato with $3,105 \mathrm{RO} /$ ha and the least profitable crop is cabbage with only $560 \mathrm{RO} / \mathrm{ha}$. The weighted average GM at farm level is 1,674 RO/ha. At farm level, the net margin (NM) or the return to land, capital and management is estimated at 1,253 RO/ha of cropped land. Given an average cropped area of nine hectares for this group then the average return to land, capital and management is 10,689 RO per farm or $890 \mathrm{RO} / \mathrm{month}$. This figure does not represent the net economic return since the cost of management, cost of capital and the opportunity cost of land are not subtracted.

Since vegetables are produced during both the winter (planted in fall) and summer (planted in March onwards) seasons, it is necessary to analyze the profitability on a per season basis. The comparison is important because water is scarce in Oman and crops grown in the summer require more water. In terms of area, almost the same cropped area is observed in winter and in summer with only a $2 \%$ reduction of

Table 2. Yields, total costs and profitability of crops in Group 1 farms.

\begin{tabular}{|c|c|c|c|c|c|c|c|c|c|}
\hline \multirow[b]{2}{*}{ Crop } & \multirow{2}{*}{$\begin{array}{c}\text { Cropped } \\
\text { Area } \\
(\%)\end{array}$} & \multicolumn{2}{|c|}{ Yield } & \multicolumn{2}{|c|}{ Operating Cost } & \multicolumn{2}{|c|}{ Gross Margin } & \multicolumn{2}{|c|}{ Net Margin } \\
\hline & & $\begin{array}{c}\text { Average } \\
\text { t/ha }\end{array}$ & $\begin{array}{l}\text { Standard } \\
\text { Deviation }\end{array}$ & $\begin{array}{l}\text { Average } \\
\mathrm{RO} / \mathrm{ha}\end{array}$ & $\begin{array}{l}\text { Standard } \\
\text { Deviation }\end{array}$ & $\begin{array}{c}\text { Average } \\
\text { RO/ha }\end{array}$ & $\begin{array}{l}\text { Standard } \\
\text { Deviation }\end{array}$ & $\begin{array}{c}\text { Average } \\
\text { RO/ha }\end{array}$ & $\begin{array}{l}\text { Standard } \\
\text { Deviation }\end{array}$ \\
\hline Tomato & 25 & 38 & 26 & 2,166 & 1,296 & 3,105 & 1,998 & 2,627 & 2,018 \\
\hline Eggplant & 1 & 8 & 2 & 2,774 & 696 & 2,839 & 1,115 & 1,392 & 145.000 \\
\hline Pepper & 5 & 15 & 10 & 1,870 & 1,161 & 1,897 & 1,097 & 1,415 & 1,112 \\
\hline Cauliflower & 1 & 15 & 18 & 1,440 & 587 & 1,112 & 500 & 821 & 635 \\
\hline Watermelon & 31 & 16 & 7 & 1,272 & 667 & 1,235 & 679 & 938 & 552 \\
\hline Potatoes & 1 & 48 & 0 & 3,955 & 3,019 & 1,769 & 794 & 1,402 & 493 \\
\hline Lettuce & 1 & 9 & 4 & 1,472 & 960 & 658 & 384 & 321 & 253 \\
\hline Melon & 27 & 14 & 7 & 1,662 & 595 & 1,217 & 968 & 854 & 1,029 \\
\hline Onion & 1 & 17 & 0 & 2,015 & 1,434 & 1,456 & 1,425 & 345 & 235 \\
\hline Cucumber & 0.1 & 24 & 24 & 2,611 & - & 1,399 & - & 365 & - \\
\hline Parsley & 0.1 & 2 & 2 & 283 & - & 660 & - & 431 & - \\
\hline Cabbage & 8 & 4 & 1 & 818 & 355 & 560 & 210 & 204 & 84 \\
\hline Bitter gourd & 1 & 6 & 1 & 1,895 & 760 & 1,087 & 228 & 407 & 176 \\
\hline Total & 100 & & & 1,662 & & 1,674 & & 1,253 & - \\
\hline
\end{tabular}




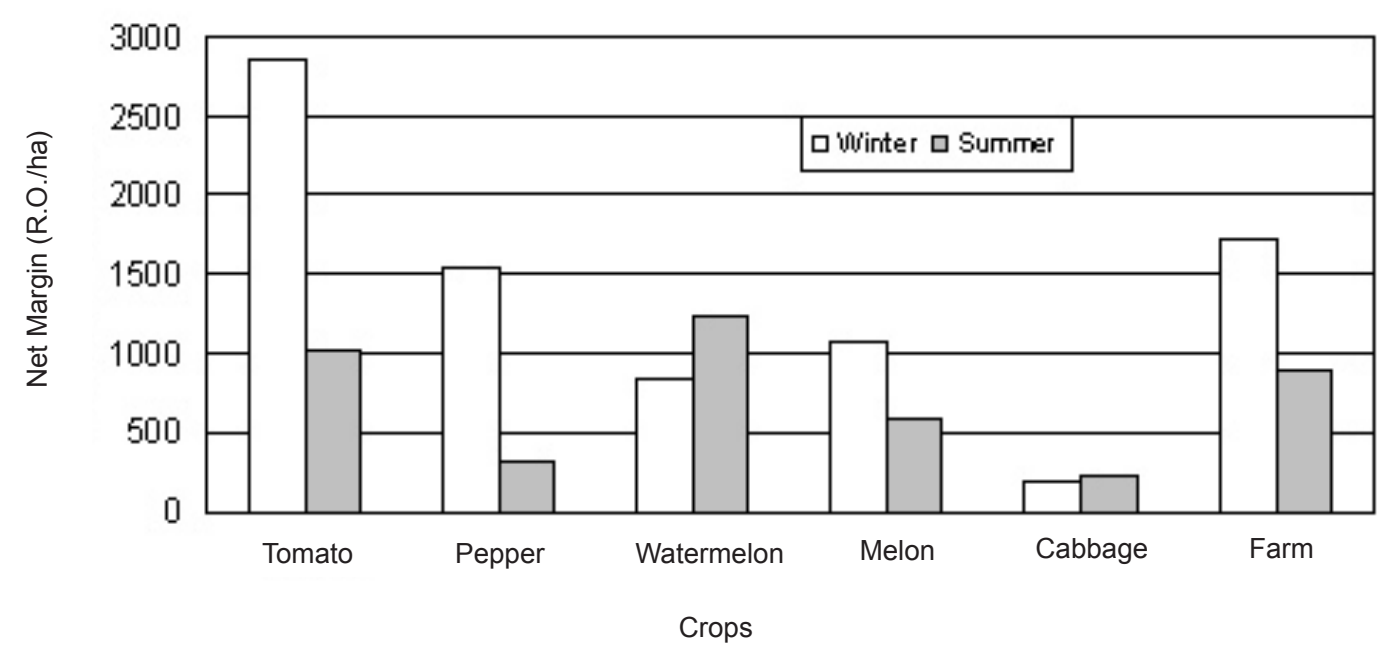

Figure 1. Main vegetable crops and their profitability per season.

area during summer. The crop mix differs between seasons: crops such as cauliflower, cucumber, lettuce, coriander and potatoes are grown only in the winter. Seventy five percent of the cropped area in winter is occupied by tomato, cabbage and watermelon. The most important crops grown in the summer are musk melon and water melon, together taking up $89 \%$ of the cropped area. Yields are higher in winter than in summer for all crops grown in both seasons except for watermelon, for which the yield in winter was $14 \mathrm{t} / \mathrm{ha}$ and in summer $16 \mathrm{t} / \mathrm{ha}$.

A comparison of the net margins for vegetables in winter and in summer is shown in Figure 1. The NM is much higher in winter than in summer for tomato, pepper and melon but cabbage and watermelon are more profitable when grown in summer. The average $\mathrm{NM}$ of winter vegetable crops is $1,655 \mathrm{RO} / \mathrm{ha}$, almost double the NM for summer vegetables of only 882 $\mathrm{RO} /$ ha. Because water is the major constraint in crop production in Oman the return to water should be considered as an indicator for water-management policy. Given that NMs are lower in summer and that crop water requirements are higher in summer, then the return to water from summer vegetables is lower than the return to water from winter vegetables. Consequently, growing vegetables in the summer should be discouraged.
Most farms in Group 1 are irrigated using modern irrigation systems, mainly the drip system. Comparison of profitability at farm level, after subtracting the depreciation and variable cost of the drip irrigation system (estimated to be $412 \mathrm{RO} / \mathrm{ha}$ ), shows that it is more profitable to use drip irrigation than furrow irrigation. The average NM for crops using the drip irrigation system is $956 \mathrm{RO} / \mathrm{ha}$, compared to $408 \mathrm{RO} /$ ha for those watered by furrow irrigation. Comparing farms, the NM of farms irrigating more than $80 \%$ of their land by the drip system is $1480 \mathrm{RO} / \mathrm{ha}$, while the NM for farms using furrow irrigation on more than $80 \%$ of their land is $670 \mathrm{RO} / \mathrm{ha}$. However it should be made clear that farms equipped with drip irrigation systems irrigate almost the same area in summer as in winter, while those using the furrow irrigation system irrigate less than $1 \%$ of the land cropped in winter in the summer. These figures illustrate clearly that, although modern irrigation systems use water more efficiently, they tend to increase water demand by allowing vegetable crops to be grown in the summer, since they provide a continuous flow of water responding to crop requirements. Thus, contrary to expectations, modern irrigation systems tend to increase, rather than reduce, groundwater pumping given the financial incentives for farmers to grow summer vegetables as well as winter vegetables. However, the double cropping of 
Table 3. Yields, total costs and profitability of crops in Group 2 farms.

\begin{tabular}{|c|c|c|c|c|c|c|c|c|}
\hline \multirow[b]{2}{*}{ Crop/Plant } & \multirow{2}{*}{$\begin{array}{c}\text { Cropped } \\
\text { area } \\
(\%)\end{array}$} & \multirow{2}{*}{$\begin{array}{c}\text { Yield } \\
\text { Ave. } \\
\text { t/ha }\end{array}$} & \multicolumn{2}{|c|}{ Operating cost } & \multicolumn{2}{|c|}{ Gross Margin } & \multicolumn{2}{|c|}{ Net Margin } \\
\hline & & & $\begin{array}{c}\text { Ave. } \\
\text { RO/ha }\end{array}$ & $\begin{array}{c}\text { Standard } \\
\text { Deviation }\end{array}$ & $\begin{array}{c}\text { Ave. } \\
\text { RO/ha }\end{array}$ & $\begin{array}{c}\text { Standard } \\
\text { Deviation }\end{array}$ & $\begin{array}{c}\text { Ave. } \\
\text { RO/ha }\end{array}$ & $\begin{array}{c}\text { Standard } \\
\text { Deviation }\end{array}$ \\
\hline Potatoes & 1 & 19 & 2,161 & - & 5,048 & - & 3,553 & - \\
\hline Cucumber & 8 & 27 & 5,354 & 4,568 & 4,301 & 3,237 & 2,197 & 2,151 \\
\hline Pepper & 3 & 17 & 2,649 & 1,954 & 2,712 & 1,934 & 1,637 & 1,171 \\
\hline Tomato & 5 & 22 & 2,642 & 1,850 & 2,691 & 1,901 & 1,049 & 1,406 \\
\hline Onion & 3 & 14 & 2,216 & 2,311 & 1,704 & 1,231 & 1,704 & 1,231 \\
\hline Watermelon & 1 & 7 & 1,182 & - & 915 & - & 246 & - \\
\hline Bitter gourd & 1 & 6 & 1,855 & 1,721 & 819 & 67 & 502 & 3 \\
\hline Lettuce & 0.4 & 2 & 213 & - & 333 & - & 168 & - \\
\hline Dates & 52 & 3 & 575 & 791 & 1,222 & 1,700 & 742 & 1,699 \\
\hline Mango & 18 & 7 & 1,216 & 2,266 & 777 & 1,154 & 385 & 883 \\
\hline Orange & 1 & 7 & 1,018 & 240 & 1,228 & 223 & 476 & 251 \\
\hline Lime & 6 & 5 & 690 & 562 & 913 & 640 & 289 & 531 \\
\hline Total & 100 & & 1,351 & & 1,522 & & 847 & \\
\hline
\end{tabular}

vegetables irrigated by drip systems still uses water more efficiently than does the cultivation of fodder crops and tree plantations (perennials).

The production potentials of vegetables are observed in the top ten percent of farms in Group 1. These farms have an average gross margin of 3,108 $\mathrm{RO} / \mathrm{ha}$ and an average net margin of 2,580 $\mathrm{RO} / \mathrm{ha}$, double the average NM of Group 1 as a whole, and have an average water salinity of $1,082 \mu \mathrm{S} / \mathrm{cm}$. On these best performing farms drip irrigation covers $87 \%$ of the cropped area and the average monthly electricity bill is $18 \mathrm{RO}$, triple the average consumption for farms in Group 1. The two most important crops are tomato and watermelon with yields of $66 \mathrm{t} / \mathrm{ha}$ and $14 \mathrm{t} / \mathrm{ha}$, respectively.

\section{Group 2: Farms growing perennials and vegetables}

More than $50 \%$ of the cropped area for farms in this group is occupied by date palm, mango and citrus trees. The remaining area grows vegetables. Table 3 shows the yield and profitability of the different crops grown by farms in Group 2. The prevailing vegetables are cucumber and tomato, with cucumber giving the highest yield at $27 \mathrm{t} / \mathrm{ha}$. The average variable cost per farm in Group 2 is $1,351 \mathrm{RO} / \mathrm{ha}$, with the variable cost of growing cucumber being the highest, at 5,354 RO/ ha. The average gross margin per farm is estimated at
1,522 $\mathrm{RO} /$ ha, with potatoes having the highest GM at 5,048 RO/ha followed by cucumber with 4,301 RO/ha. The average NM per farm is $847 \mathrm{RO} / \mathrm{ha}$.

Finally, a comparison of the profitability of vegetables and that of tree crops shows that vegetables are more profitable, except for lettuce, which is less profitable than tree crops. A comparison of the average net margins of Groups 1 and 2 shows that Group 1 is significantly the more profitable with a NM of 1,253 $\mathrm{RO} /$ ha, while the NM of Group 2 is only $847 \mathrm{RO} / \mathrm{ha}$, a difference of $406 \mathrm{RO} / \mathrm{ha}$.

\section{Group 3: Farms growing fodder crops and vegetables}

In this group of farms vegetable crops represent only $21 \%$ of the cropped area. As shown in Table 4 the most important vegetable crop, in terms of area, is onion with eight percent of the area. The average variable cost is $738 \mathrm{RO} /$ ha at farm level and the crop with the highest cost is potato with $2,100 \mathrm{RO} / \mathrm{ha}$. In terms of profitability the highest GM is obtained for garlic with 3,167 RO/ha; the lowest GM is observed for onion with $706 \mathrm{RO} / \mathrm{ha}$; and the highest GM for any fodder crop is for alfalfa, with $2,948 \mathrm{RO} / \mathrm{ha}$. Fodder crops are usually sold as green fodder. At farm level the weighted average GM is $1,876 \mathrm{RO} /$ ha which is higher than the GMs obtained for farms in Groups 1 and 2. 
Table 4. Yields, total costs and profitability of crops in Group 3 farms.

\begin{tabular}{|c|c|c|c|c|c|c|c|c|c|}
\hline \multirow{2}{*}{ Crop/Plant } & \multirow{2}{*}{$\begin{array}{c}\text { Cropped } \\
\text { Area } \\
(\%)\end{array}$} & \multicolumn{2}{|r|}{$\begin{array}{l}\text { Yield } \\
\text { (t/ha) }\end{array}$} & \multicolumn{2}{|c|}{$\begin{array}{l}\text { Total Cost } \\
\text { (RO/ha) }\end{array}$} & \multicolumn{2}{|c|}{$\begin{array}{l}\text { Gross Margin } \\
(\mathrm{RO} / \mathrm{ha})\end{array}$} & \multicolumn{2}{|c|}{$\begin{array}{l}\text { Net Margin } \\
\text { (RO/ha) }\end{array}$} \\
\hline & & Ave. & $\begin{array}{c}\text { Standard } \\
\text { Deviation }\end{array}$ & Ave. & $\begin{array}{c}\text { Standard } \\
\text { Deviation }\end{array}$ & Ave. & $\begin{array}{l}\text { Standard } \\
\text { Deviation }\end{array}$ & Ave. & $\begin{array}{c}\text { Standard } \\
\text { Deviation }\end{array}$ \\
\hline Garlic & 3 & 5 & & 1,605 & & 3,167 & & 2,348 & \\
\hline Potatoes & 3 & 29 & & 2,100 & & 3,512 & & 2,185 & \\
\hline Onion & 8 & 18 & & 1,518 & & 706 & & 268 & \\
\hline Tomato & 5 & 8 & 3 & 1,173 & 503 & 1,046 & 570 & 351 & 36 \\
\hline Alfalfa & 40 & 71 & 50 & 622 & 319 & 2,948 & 1,985 & 2,493 & 1,561 \\
\hline Maize & 34 & 1 & & 294 & & 630 & & 420 & \\
\hline Baffle grass & 11 & 71 & 41 & 792 & 728 & 1,592 & 911 & 994 & 626 \\
\hline Rhodes grass & 13 & 7 & & 471 & & 522 & & 243 & \\
\hline Total & 105 & & & 738 & & 1,876 & & 1,412 & \\
\hline
\end{tabular}

The average NM is $1,412 \mathrm{RO} / \mathrm{ha}$, which is the highest NM found in any of the four groups of farm and which appears to show that the highest level of farm profitability is linked to fodder production. Since this study used only prices for 2005/06, this result should be considered with some care due to price variations from year to year.

\section{Group 4: Farms growing a mixture of crops}

This group is composed of farms growing vegetables (38\%), tree crops (or perennials) (44\%) and fodder crops (18\%). The average farm size is 3.37 ha and on average a farm grows eight crops (Table 5). The most important vegetable crop is tomato representing $16 \%$ of the area, followed by watermelon and muskmelon with 8 and $5 \%$ of the area, respectively; the most important fodder crop is Rhodes grass, taking 13\% of the cropped area; and the most important perennial (or tree crop) is dates, with date palms taking $33 \%$ of the cropped area. On average, variable costs are $701 \mathrm{RO} /$ ha with cucumber having the highest variable costs at $6,638 \mathrm{RO} /$ ha and mango the lowest at only $155 \mathrm{RO} /$ ha. Among vegetables the highest GM is obtained for tomato with 3,854 RO/ha. The average GM per farm is $1,559 \mathrm{RO} /$ ha and the average $\mathrm{NM}$ is $1,187 \mathrm{RO} / \mathrm{ha}$, which is the second best NM among the four groups.

\section{Comparisons of farm performance}

In this section we compare the profitability of the four groups of farms. The highest average gross margin per group is obtained by farms in Group 3, producing fodder crops and vegetables as shown in Figure 2. The highest average net margin per group at 1,412 RO/ha is also found in Group 3; thus the most profitable type of farming appears to be a mixture of fodder crops and vegetables. The second highest average NM is found among farms in Group 1 at 1,253 RO/ha, which is only $160 \mathrm{RO} /$ ha less than the average NM for Group 3 farms.

The average NM of all farms is $1,179 \mathrm{RO} /$ ha with a standard deviation of $889 \mathrm{RO} / \mathrm{ha}$, and a coefficient of variation of $76 \%$ between farms. For Group 1 farms the standard deviation is $936 \mathrm{RO} / \mathrm{ha}$, with a coefficient of variation of $75 \%$. The highest coefficient of variation is observed among Group 2 farms at $83 \%$ and the lowest coefficient of variation, $55 \%$, is found among farms in Group 3. This may indicate that a mixture of fodder crops and vegetables is the least risky type of farming.

These figures indicate that in all groups profitability variation among farms of the same group is very high. This may be due to the absence of organization and communication among farmers, which may hold back diffusion of the best management practices. Since all these farms experience similar environmental conditions, the reasons for the wide discrepancies among farms are most likely to be related to the way these farms are managed, though the availability and quality of irrigation water might also explain part of the profitability differences among farms of a given group.

Table 6 shows the water salinity levels per farm group. The average salinity level of the surveyed farms is $1642 \mu \mathrm{S} / \mathrm{cm}$. Most of the farms (84\%) have a 
Table 5. Yields, total costs and profitability of crops in Group 4 farms.

\begin{tabular}{|c|c|c|c|c|c|c|c|c|c|}
\hline \multirow{2}{*}{ Crop/Plant } & \multirow{2}{*}{$\begin{array}{c}\text { Cropped } \\
\text { Area } \\
(\%)\end{array}$} & \multicolumn{2}{|c|}{$\begin{array}{l}\text { Yield } \\
(\mathrm{t} / \mathrm{ha})\end{array}$} & \multicolumn{2}{|c|}{$\begin{array}{l}\text { Operational cost } \\
\text { (RO/ha) }\end{array}$} & \multicolumn{2}{|c|}{$\begin{array}{l}\text { Gross Margin } \\
\text { (RO/ha) }\end{array}$} & \multicolumn{2}{|c|}{$\begin{array}{l}\text { Net Margin } \\
\text { (RO/ha) }\end{array}$} \\
\hline & & Ave. & $\begin{array}{c}\text { Standard } \\
\text { Deviation }\end{array}$ & Ave. & $\begin{array}{c}\text { Standard } \\
\text { Deviation }\end{array}$ & Ave. & $\begin{array}{c}\text { Standard } \\
\text { Deviation }\end{array}$ & Ave. & $\begin{array}{c}\text { Standard } \\
\text { Deviation }\end{array}$ \\
\hline Eggplant & 1 & 7 & & 1,263 & & 3,150 & & 2,308 & \\
\hline Cucumber & 1 & 38 & & 6,638 & & 2,919 & & 981 & \\
\hline Tomato & 16 & 36 & & 1,030 & 230 & 3,854 & 1,414 & 3,434 & 1,493 \\
\hline Pepper & 1 & 18 & & 1,394 & & 3,019 & & 2,177 & \\
\hline Watermelon & 8 & 27 & 29 & 1,503 & 453 & 1,641 & 1,027 & 878 & 894 \\
\hline Melon & 5 & 14 & & 1,556 & & 2,159 & & 1,302 & \\
\hline Garlic & 2 & 4 & 5 & 262 & 94 & 848 & 875 & 666 & 829 \\
\hline Parsley & 2 & 2 & & 751 & & 654 & & 440 & \\
\hline Onion & 2 & 3 & & 375 & 123 & 378 & 77 & 197 & 123 \\
\hline Dates & 33 & 3 & 3 & 181 & 67 & 974 & 1,102 & 814 & 1,094 \\
\hline Lime & 5 & 3 & 1 & 514 & 558 & 1,052 & 1,196 & 864 & 1,169 \\
\hline Mango & 4 & 4 & 2 & 155 & 84 & 441 & 218 & 286 & 302 \\
\hline Orange & 2 & 2 & 0 & 202 & 152 & 229 & 81 & 74 & 165 \\
\hline Alfalfa & 3 & 36 & & 942 & & 1,657 & & 843 & \\
\hline Baffle grass & 1 & 89 & & 1,892 & & 2,165 & & 340 & \\
\hline Maize & 1 & 4 & & 371 & & 2,844 & & 2,629 & \\
\hline Rhodes grass & 13 & 12 & & 520 & & 418 & & 195 & \\
\hline Total & 100 & & & 701 & & 1,559 & & 1,187 & \\
\hline
\end{tabular}

moderate salinity level and only $2 \%$ of the farms have a low level of salinity with less than $300 \mu \mathrm{S} / \mathrm{cm}$. Group 3 and Group 4 have the highest percentages of farms with water salinity exceeding $2500 \mu \mathrm{S} / \mathrm{cm}$.

Observation of farms in Group 1 shows that melon, watermelon and cucumber are not grown in farms with high salinity. Differences in yield vary from crop to crop when farms with moderate salinity are compared to farms with high salinity. For instance, for tomato the average yield for farms with moderate salinity was $37 \mathrm{t} / \mathrm{ha}$ but for those with high salinity the yield was $31 \mathrm{t} / \mathrm{ha}$; for pepper the yield dropped more markedly from $14 \mathrm{t} / \mathrm{ha}$ to only $6 \mathrm{t} / \mathrm{ha}$. The average GM was 1,804 $\mathrm{R} / \mathrm{ha}$ for farms having moderate salinity compared to a GM of $1,171 \mathrm{R} /$ ha for farms with high salinity. These figures are merely indicative and should not be generalized as the sample was not large enough to address specifically the salinity problem. Besides, the use of inputs varies between farms, which also causes GM differences. In other words, differences in gross margin among the farms with moderate salinity and those with high salinity could not be attributed to the water salinity variable alone.

\section{Farmers'Awareness and Groundwater Salinization}

Given the scarcity of water and its quality degradation farmers were interviewed about water management, the reasons for increasing salinization and possible remedies. Table 7 shows well depth in 2005 and decisions to deepen wells in that year. On average the well depth was 39.2 meters. In 2005 twenty seven percent of farmers deepened their wells by an average of 11.8 meters. Those farmers who deepened their wells were all looking for more water and $23 \%$ of farmers were looking for lower salinity levels.

Since wells are not equipped with water-flow meters the consumption of electricity is used as a proxy for water use. On average, farms are spending 9.735 $\mathrm{RO} /$ month/ha on electricity. Given that the depths of the wells vary between the four groups of farms, the monthly cost of electricity/ha/meter of well depth was estimated to allow comparison. The figures vary between a low of $0.208 \mathrm{RO} / \mathrm{ha} / \mathrm{month} /$ meter for farms in Group 3 and a high of $0.389 \mathrm{RO} / \mathrm{ha} /$ month/meter for Group 4 farms. Surprisingly, for Group 1 farms, all of which grow only vegetables, the average electricity 


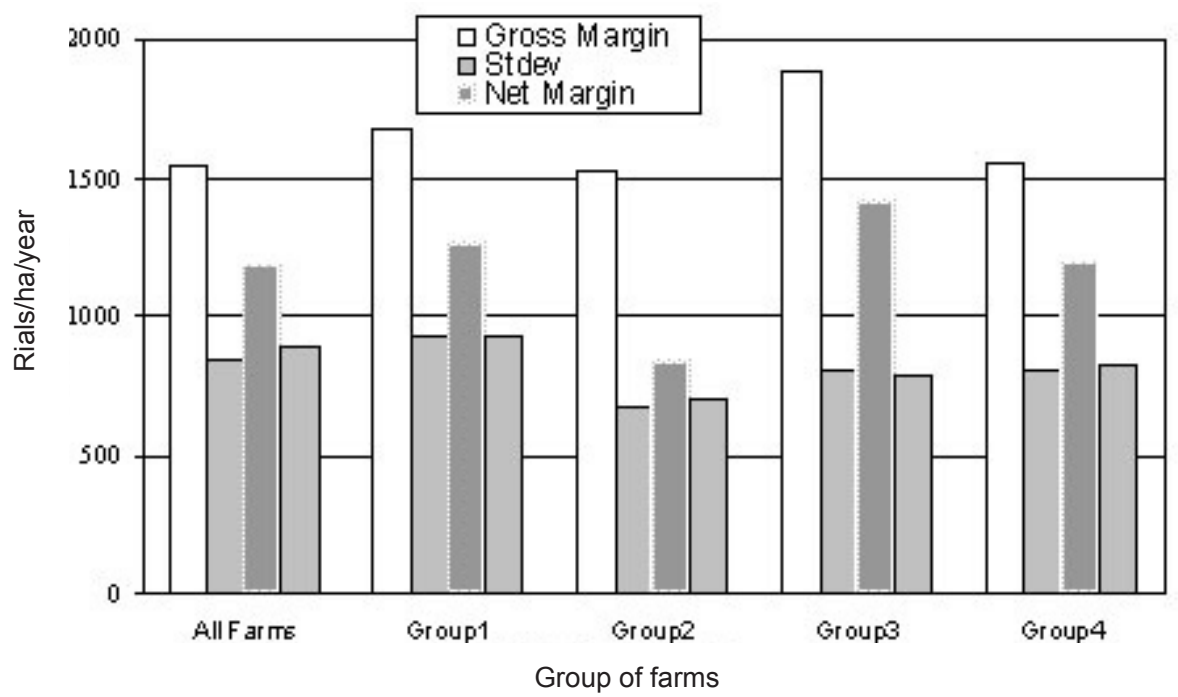

Figure 2. Gross and net margins per farm group and standard deviations.

consumption is $0.230 \mathrm{RO} / \mathrm{ha} / \mathrm{month} /$ meter while for Group 3, in which farms produce fodder crops and vegetables, the consumption of electricity and hence water is the lowest of all.

The cultivation of fodder crops in the Batinah is thought to require the greatest amount of water and is thus identified as an important cause of the overabstraction of groundwater. Our results show that the type of farms using the highest quantity of electricity, and hence the highest volumes of water, are those in Groups 2 and 4 where tree crops occupy 54\% and $23 \%$ respectively of the cultivated area. The average

Table 6. Irrigation water salinity level per farm Group.

\begin{tabular}{|c|c|c|c|c|c|c|}
\hline & $\begin{array}{l}\text { Average } \\
\text { Salinity } \\
(\mu \mathrm{S} / \mathrm{cm})\end{array}$ & $\begin{array}{c}\text { Max } \\
\text { Salinity } \\
(\mu \mathrm{S} / \mathrm{cm})\end{array}$ & $\begin{array}{c}\text { Min } \\
\text { Salinity } \\
(\mu \mathrm{S} / \mathrm{cm})\end{array}$ & $\begin{array}{l}\text { Low } \\
\text { Salinity } \\
(<300 \mu \mathrm{S} / \\
\mathrm{cm})(\%)\end{array}$ & $\begin{array}{c}\text { Moderate } \\
\text { Salinity } \\
(300< \\
>2500 \mu \mathrm{S} / \\
\mathrm{cm})(\%)\end{array}$ & $\begin{array}{l}\text { High } \\
\text { Salinity } \\
(>2500 \mu \mathrm{S} / \\
\mathrm{cm})(\%)\end{array}$ \\
\hline All farms & 1642 & 11330 & 242 & 2 & 84 & 14 \\
\hline $\begin{array}{l}\text { Group 1: } \\
\text { Vegetables }\end{array}$ & 1994 & 11330 & 622 & 0 & 85 & 15 \\
\hline $\begin{array}{l}\text { Group 2: } \\
\text { Tree Crops and } \\
\text { Vegetables }\end{array}$ & 1245 & 3010 & 242 & 6 & 88 & 6 \\
\hline $\begin{array}{l}\text { Group 3: } \\
\text { Fodder and } \\
\text { Vegetables }\end{array}$ & 1827 & 3240 & 322 & 0 & 67 & 33 \\
\hline $\begin{array}{l}\text { Group 4: } \\
\text { Mixed }\end{array}$ & 1436 & 3480 & 580 & 0 & 75 & 25 \\
\hline
\end{tabular}


Table 7. Wells: depth, management and electricity consumption.

\begin{tabular}{|c|c|c|c|c|c|c|c|}
\hline & $\begin{array}{l}\text { Average } \\
\text { Well } \\
\text { Depth } \\
\text { (m) }\end{array}$ & $\begin{array}{c}\text { Farms } \\
\text { Increasing } \\
\text { Well Depth } \\
\text { during } \\
2005 \\
(\%)\end{array}$ & $\begin{array}{l}\text { Average } \\
\text { Increase in } \\
\text { Depth } \\
\text { (m) }\end{array}$ & $\begin{array}{l}\text { Looking } \\
\text { for Better } \\
\text { Quality } \\
\text { Water } \\
(\%)\end{array}$ & $\begin{array}{l}\text { Looking } \\
\text { for more } \\
\text { Water } \\
(\%)\end{array}$ & $\begin{array}{l}\text { Monthly } \\
\text { Cost of } \\
\text { Electricity } \\
\text { (RO/ha) }\end{array}$ & $\begin{array}{l}\text { Ratio of } \\
\text { Monthly Cost } \\
\text { of Electricity } \\
\text { to Well Depth } \\
\text { (RO/ha/meter) }\end{array}$ \\
\hline All farms & 39.2 & 27 & 11.78 & 23 & 100 & 9.735 & 0.248 \\
\hline $\begin{array}{l}\text { Group 1: } \\
\quad \text { Vegetables }\end{array}$ & 26.6 & 26 & 3.21 & 33 & 100 & 6.111 & 0.230 \\
\hline $\begin{array}{l}\text { Group 2: } \\
\text { Tree Crops and } \\
\text { Vegetables }\end{array}$ & 62.3 & 29 & 25.88 & 0 & 100 & 23.605 & 0.379 \\
\hline $\begin{array}{l}\text { Group 3: } \\
\text { Fodder and } \\
\text { Vegetables }\end{array}$ & 40.0 & 40 & 2.262 & 50 & 100 & 8.318 & 0.208 \\
\hline $\begin{array}{l}\text { Group 4: } \\
\text { Mixed }\end{array}$ & 27.2 & 0 & 0 & 0 & 0 & 10.588 & 0.389 \\
\hline
\end{tabular}

electricity bill for farms in Group 2 is nearly four times higher than the average bill for farms in Group 1 , which would indicate excess water application to tree crops. However, for cultural reasons, it is hard to implement any policy to reduce the area of plantations mainly occupied by date palms.

When farmers were asked about the salinization of the groundwater, $47 \%$ said that they were concerned by this problem. Eighty seven percent identified overpumping as the reason for the salinization problem. This high percentage shows the awareness of farmers about the main cause of the problem. Farmers were then presented with four options to reduce the overpumping of groundwater: the results are presented in Figure 3. The most frequently chosen option was to ban irrigation during the summer season $(47 \%$ of the responses); $39 \%$ of respondents chose banning the production of fodder crops; $11 \%$ of farmers chose increasing electricity prices; the least popular option was establishing water quotas, chosen by only $3 \%$ of farmers.

Farmers were also asked what solutions they would propose to reduce groundwater over-pumping (see Figure 4). Twenty seven percent proposed a ban on growing fodder crops; $20 \%$ suggested using desalinated water for irrigation; $13 \%$ proposed increasing well depth and another 13\% proposed introducing modern irrigation systems; 7\% proposed the use of treated wastewater; while $13 \%$ still think that greater rainfall in the future will solve the problem of salinization. These suggestions contradict the result in the paragraph above where $87 \%$ of the farmers recognized that over-pumping is the main cause of seawater intrusion and hence salinization. Actually, most of the farmers considered that the salinity problem was caused by "others". Many farmers still appear to believe that the limits of water pumping have not been reached, because they proposed increasing well depth. Not a single farmer proposed cooperation between farmers and common management of water resources as a solution to the problem. Finally, $20 \%$ of farmers proposed that the Government desalinates water for agricultural uses; thus implying that farmers expected someone else (the Government) to solve the problem they (the farmers) are causing and at a cost higher than the benefit for society. These results suggest the need for an extension program for farmers focussing on the necessity for a reduction in groundwater pumping and the mechanisms by which this might be achieved.

\section{Possible Implications of Banning the Cultivation of Fodder Crops in the Batinah}

One of the policy options being considered by the Government is a ban on the cultivation of fodder crops 


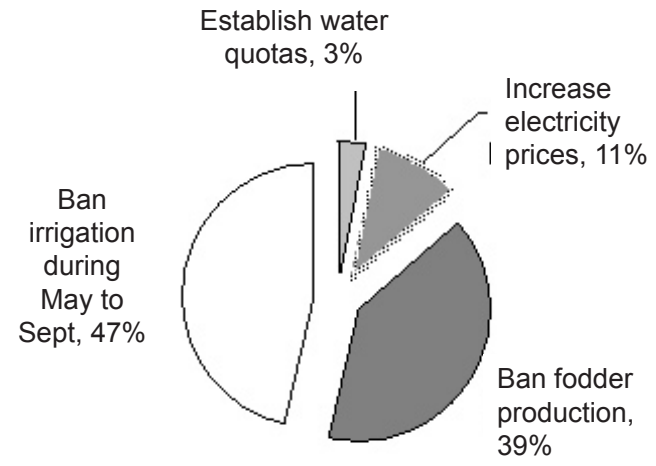

Figure 3. Farmers' opinions about measures to control groundwater extraction.

on Batinah farms larger than 13 ha and the transfer of cultivation of these crops to the Nejed area. The main objective of this policy is the reduction of groundwater pumping to minimize seawater intrusion. The current area of fodder crops in the Batinah is 9,687 ha while the total area of vegetables is only 4,070 ha (MAF, 2006). Such a ban would seem to present the opportunity to expand the area of vegetable crops, since most fodder growers are likely to shift to vegetables, largely because vegetables are seasonal crops with immediate profitability. But fodder producers would first need to upgrade their irrigation systems from sprinklers to the drip system; this could apply to over 5,000 ha.

One immediate consequence of such a switch from fodder to vegetable production would be an increase in supply and a subsequent fall in price, unless more vegetables are exported. However, in the short run it is unlikely that greater exports could be achieved since there are no farmers' boards and farmers lack organization. In addition, it is hard to believe that farmers more used to producing fodder crops could, in the short run, produce the high quality vegetables demanded by international markets. In terms of the demand for water, a comparison of vegetable farms with farms producing fodder, shows that the former use slightly more water, as shown by the demand for electricity (see Table 7). Consequently, banning the cultivation of fodder crops will not allow water saving.

From a financial point of view, current vegetable farmers as well as farmers who switch to growing vegetables would suffer a fall in income. The former will lose as a consequence of an excess supply of vegetables, at least in the short run. Incomes in the latter group would fall for two reasons, the first is that vegetable cropping is less profitable than fodder production and the second is that vegetable prices would fall, as mentioned above. Another issue concerns the shortage of agricultural labor due to restrictions on the number of visas for laborers from neighboring countries. Most fodder production is mechanized, but

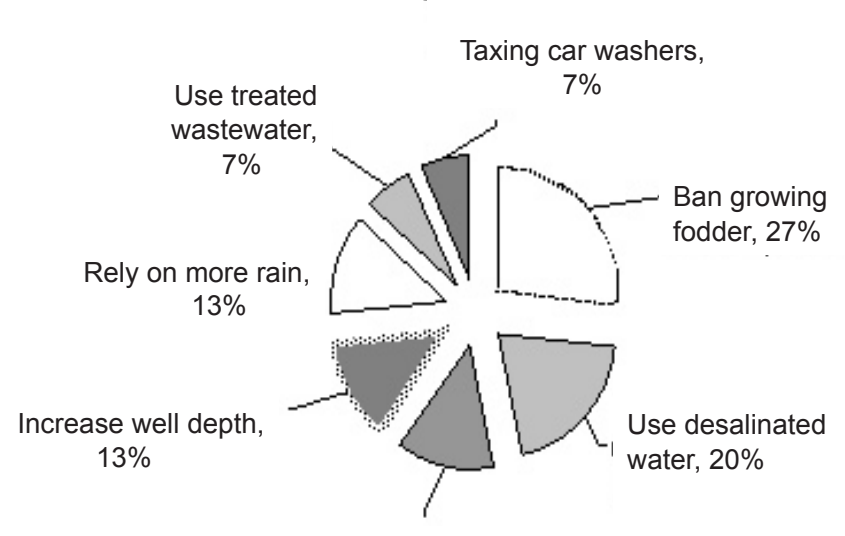

Use MIS, $13 \%$

Figrue 4. Farmers' suggestions to circumvent the water salinization problem. 
vegetable production is labor intensive and would thus become much more costly.

\section{Conclusions}

In this paper a sample of 49 small-scale farms in the Batinah has been studied, using interviews with farmers and surveys. Yields, variable costs and profitability were estimated. We observed that vegetable yields differ significantly among farmers, as is indicated by the high standard deviations. These yield gaps might be reduced by extension programs for vegetable growers, which focus on the best management practices.

In financial terms farming in the Batinah is a profitable activity, with even the lowest average net margin per group being $847 \mathrm{RO} / \mathrm{ha} /$ year in 2005 - this was for the fruit and vegetable farms forming Group 2. Against expectations, the highest average net margin of 1,412 RO/ha/year was obtained for Group 3, in which farms produce fodder crops and vegetables. Though all four groups' average net margins are high enough, the standard deviations point to large variations in profitability between farms. This implies that the full potential of economic productivity has not yet been reached.

The top $10 \%$ of vegetable farms growing only vegetables (Group 1) registered a net margin of 2,580 RO/ha, double the average net margin of the whole group. However, these top farms operate in an environment characterized by moderate salinity, which is not the case for all farms in the Batinah. Even if better water quality does explain part of the high net margins obtained by some farmers, there are technical deficiencies as well as economic barriers that should be looked at to improve farmers' returns in the region. From a purely technical point of view, yields are still lower than can be found in other countries. One example is tomato where the highest observed yield was $66 \mathrm{t} / \mathrm{ha}$, far from the widespread $100 \mathrm{t} /$ ha achieved in several developed and less developed countries; similarly, the yields reported for cabbage are particularly low. From an economic point of view, helping farmers to get organized and work together should be considered in order to reduce production costs, improve marketing and increase prices received.

The crop mix in all farm groups shows a large number of crops being cropped at a time. The farms considered in this study are market oriented. The mix of several crops is an indication of absence of specialization, but it is also a mean of reducing risk. The high variation of yields among farmers for the same crop calls for diffusion of the results obtained in several research projects.
The expected ban on growing fodder crops in the Batinah area, and the transfer of such cultivation to the Nejed area, might lead to an increased supply of vegetables in the local market and a subsequent price fall for farmers in the short run. However, the expected expansion of vegetables in the Batinah is an excellent opportunity to promote best management practices and increase productivity in the years to come.

\section{Acknowledgments}

This research was funded by His Majesty's Strategic Research Project (SR/AGR/PLNT/04/01) awarded to Dr. Iqrar Khan. The authors are grateful to Murei AlBarhi for his assistance with this investigation.

\section{References}

Dellapenna, D. 2001. Nutritional genomics. Science 285:375-379.

Gardner, G. and B. Halweil. 2000. Underfed and Overfed: The Global Epidemic of Malnutrition. Worldwatch Paper 150. Worldwatch Institute. Washington, DC, U.S.A.

Khaw, K., S. Bingham, A. Welch, R. Luben, N. Wareham, S. Oakes, and N. Day. 2001. Relation between plasma ascorbic acid and mortality in men and women in EPIC-Norfolk prospective study: a prospective population study. The Lancet 357: 657-663.

Ministry of Agriculture and Fisheries. 2006. Agricultural Census 2004/2005. Ministry of Agriculture and Fisheries. Sultanate of Oman.

Ministry of National Economy. 2007. Economic development strategy and the growth of the agricultural sector. Workshop on the Agricultural Sector Sustainable Development and Labor Market. 10-12 February, 2007. Ministry of National Economy, Samail, Sultanate of Oman.

Omezzine, A., G.V. Chomo and O. Al-Jabri. 1998. Demand analysis of selected fruits and vegetables in Oman. SQU Journal of Scientific Research - Agricultural Sciences 3:19-26.

Rehmatullah, X. 1996. Diagnostic criteria for fertilizing irrigated potatoes on entisols under arid climate of Oman. Pakistan Journal of Soil Sciences 12:45-50.

Satti, S.M.E., M. Lopez and S.A. Al-Rawahi. 1995. Effect of saline nutrient solutions on growth and accumulation of mineral elements in some tomato cultivars. Communication in Soil and Plant Analysis 26:21.

Received: June 2007

Accepted: November 2007 